\title{
Outbreak of COVID-19: Economic Shocks and Corporate Responses in India
}

\author{
Santanu Bhadra ${ }^{1}$, Sougata Ray ${ }^{2}$ \\ ${ }^{1}$ Business Policy and Strategy, Indian Institute of Management, Raipur, India, ${ }^{2}$ Strategy and Entrepreneurship, Indian School of Business, Hyderabad, \\ India \\ Keywords: covid-19, india, corporate responses \\ https://doi.org/10.46557/001c.27114
}

\section{Asian Economics Letters}

Vol. 3, Issue 2, 2022

\begin{abstract}
Although COVID-19 caused initial shocks to the Indian economy, a quick recovery was visible within a few months. We systematically analyze corporate responses during the lockdown period and argue that corporate resilience through proactive responses played a key role in this recovery. We find that, apart from operational continuity, Indian firms mostly focused on reducing employee costs and launching new products or services for surviving the crisis.
\end{abstract}

\section{Introduction}

The COVID-19 pandemic has created not only a major public health crisis around the world, but also an unprecedented shock to the global economy, particularly due to the sudden and severe lockdown measures adopted by many governments. These have caused business disruptions in every sector of the economy, from both the supply and demand sides. India, a country of around 1.3 billion people, was feared to be one of the worst hit by the pandemic and related economic disruptions. At one point, the International Monetary Fund (IMF) forecasted that India's gross domestic product (GDP) could shrink by more than $10 \%$. The Reserve Bank of India (RBI), India's central bank, also predicted the GDP would decline by $9.5 \%$ in its Monetary Policy Report in October 2020. However, both the IMF and the RBI had to revise their estimates to an $8 \%$ decline in their April 2021 reports, indicating a better than expected performance of the Indian economy during the year. The year-on-year growth of the monthly Index of Industrial Production sharply recovered, from $-57.3 \%$ in April 2020 to $+1.0 \%$ in September 2020. From September 2020, collections of the monthly Goods and Services Tax (GST) also showed a positive growth on a year-on-year basis. These results reflect the resilience of corporate India to survive the initial shock. However, there is a lack of systematic study on the corporate actions that helped induce such resilience in the Indian economy.

We observe the policy interventions by the RBI and the Indian government to revive the economy. Both monetary policy and fiscal stimuli were announced to increase liquidity in the market and support industrial activities. At the same time, our contention is that policy measures alone cannot pull the economy out of such crisis, unless the individual companies can survive the initial shock through proactive responses. Thus, our research question is the following: what were the initial responses of the Indian corporate sector to the COVID-19 outbreak?

Research on the COVID-19 pandemic has two major focus areas: a) the health crisis, where studies have been mostly devoted to modeling the spread of the virus and other impacts on public health, and b) the economic crisis, where studies have been concerned with the various economic impacts during the period (Padhan \& Prabheesh, 2021). Within the economic crisis literature, studies have primarily looked into the impacts on stock markets, capital markets, labor markets, and consumption behaviors (Sha \& Sharma, 2020; Sharma \& Sha, 2020). However, little attention has been paid to corporate responses in surviving the initial shock, which is an important aspect of the economic resilience supplementing government policies.

In this study, we systematically analyze corporate responses to the COVID-19 outbreak in the Indian context. Based on content analysis of newspaper articles, we find that Indian companies mostly responded by reducing employee costs and launching new products or services, apart from focusing on operational continuity. Considerable attention has also been directed toward social responsibility under the COVID-19 scenario.

\section{Context}

In the initial period, the COVID-19 crisis posed immense uncertainties, not only in terms of the spread of the virus, but also in terms of government lockdown policies (Iyke, 2020). Just after the first lockdown phase (March 25 to April $14,2020)$ in India, electricity demand reduced to $30 \%$, oil demand lessened by $70 \%$, and Indian rail activity was below $36 \%$ compared to last year (Ghosh et al., 2020). Restrictive interventions by governments to fight COVID-19 adversely 
impacted economic activities, as reflected by stock market indices (Ashraf, 2020; Yang \& Deng, 2021). Although the Indian government announced a total economic package of Rs 20.9 lakh crores-around US\$0.28 trillion, $10 \%$ of India's GDP-most of it was via the RBI's liquidity measures (3.8\% of the GDP) and indirect fiscal measures such as loans and guarantees (5\% of the GDP). Direct fiscal spending by the government comprised merely $1.2 \%$ of the GDP. During such uncertainties, firms are more likely to adopt innovative approaches (Han \& Qian, 2020; Shen et al., 2020), and their individual efforts towards business continuity and finding new ways of doing business can accelerate economic recovery.

Firms respond in different ways during crises. Many just try to persevere, given a threat situation, and, at the same time, others seek opportunities to either innovate business models or restructure operations (Wenzel, 2021). Thus, firms' strategic choices can determine whether they come out stronger or weaker from the crisis. In the case of COVID-19, firms around the world have responded to the crisis in different ways, starting from cost rationalization (Lund et al., 2020) and finding market opportunities (Buehler et al., 2020), to work-from-home policies and digital ways of organizing (Agrawal et al., 2020; Boland et al., 2020). In this study, we seek to understand the initial responses of Indian companies in continuing economic activities during the COVID-19 shock.

\section{Methodology}

We undertake the content analysis of newspaper articles to understand the responses of Indian firms during the COVID-19 outbreak. Content analysis is suitable for analyzing text data by employing both quantitative and qualitative approaches (Gaur \& Kumar, 2018). Content analysis can be carried out through various means, including manual coding and word frequency and topic modeling (Gaur \& Kumar, 2018). In this analysis, we used manual coding techniques to categorize corporate responses at different levels. News articles published during the crisis provide rich data about how firms responded to the crisis. We searched for news articles pertaining to specific responses by firms in this situation. We first determined our sample period, as follows.

The World Health Organization declared COVID-19 a pandemic on March 11, 2020. Many countries went into lockdown around that time. India imposed its first nationwide lockdown on March 23, marking the start of economic disruption around the country. The country remained under full lockdown until the first week of June and then remained under partial lockdown in the following months. We thus use a sample period from April 1 to June 30, which covers the major lockdown period, as well as the first quarter of the financial year (India's GDP estimates are based on the financial year from April to March of next year). This early period in the crisis is ideal for assessing proactive corporate responses, because government relief measures were announced later, in a staggered manner, which could have been mediated by reactive corporate responses.

After deciding on the sample period, we conducted an extensive search for newspaper articles that contained any firm-specific response in terms of action taken in relation to the COVID-19 situation. We collected digital copies of newspapers (e-papers) from politrix.com and dailyepaper.in. We collected e-papers from April 1 to June 30, which is the first financial quarter during the lockdown period in India. We focused on the following newspapers whose digital copies are readily available and mostly business related: Business Line, The Economic Times, The Financial Express, and Mint. Our search process was both keyword based and based on general scanning. The keyword-based search is faster for finding articles, but it depends on the keywords to find the right kind. The following keywords were used: covid, corona, pandemic, and lockdown. We assumed that any COVID-19-related corporate response would contain at least one of these keywords. Our purpose with the keywords was to find the right articles, as opposed to analyzing the keywords themselves. We also manually scanned the newspapers to augment the news items in case these keywords were not sufficient. We used these articles to categorize corporate responses by coding into action items at the first level, and then into action categories at the second level (see Table 1).

\section{Findings}

Panel A in Table 1 depicts the number of news articles collected by the search process. After removing duplicate news reports, we found a total of 242 firm-specific news items (involving 158 firms) related to the COVID-19 scenario. Lack of availability of e-papers was high for Business Line and Mint; however, The Economic Times and The Financial Express covered all the days in April through June, with an overlap of around $85 \%$ of the days between the two. Among all these news items, we found 206 that were related to corporate responses, with the rest related to opinions or financial impact. Hence, our final sample comprises 206 news items representing corporate responses during a three-month period.

Our analysis primarily reveals that Indian corporate responses can be identified under four main categories: the business continuity, cost restructuring, new opportunities, and social responsibility. There is also variation in how firms responded under these broader categories.

We show the categorization results in Panel B of Table 1. The share of response categories in percentage terms helps us interpret the focus areas of corporate India. We find that Indian firms focused not only on business continuity (32.6\%), but also cost restructuring (25.8\%) as well as new opportunities (30.6\%). In terms of business continuity, they primarily tried to continue operations, such as by working from home or resuming operations as soon as possible (21.4\%). While looking for way to restructure costs, firms mostly cut down on employee costs through layoffs and salary cuts (20.4\%), vis-à-vis cutting other costs (3.4\%). On the other hand, firms also found new opportunities in terms of new products or services suited to the new normal (19.9\%). Albeit relatively fewer, new partnerships with complementary businesses also formed in this period (3.4\%). Finally, many firms displayed social responsibility by manufacturing COVID-19-related products or providing community services (11.0\%). Such proactive responses from India corporations kept them resilient and, in turn, played a 
Table 1. Sample and results

Panel A: Number of news articles collected in the primary sample

\begin{tabular}{|c|c|c|}
\hline Newspaper name & & Article count \\
\hline Economic Times & & 71 \\
\hline Financial Express & & 140 \\
\hline Mint & & 19 \\
\hline Business Line & & 12 \\
\hline \multicolumn{3}{|c|}{ Panel B: Categories of news items related to specific firm actions } \\
\hline Action Categories & Action Items & $\%$ of News Items \\
\hline \multirow[t]{4}{*}{ Business Continuity } & continue operations & $21.4 \%$ \\
\hline & maintain contracts & $6.3 \%$ \\
\hline & maintain employee cost & $4.9 \%$ \\
\hline & cut employee cost & $20.4 \%$ \\
\hline \multirow{3}{*}{ Cost Restructure } & cut other costs & $3.4 \%$ \\
\hline & cut investment budget & $1.0 \%$ \\
\hline & renegotiate contracts & $1.0 \%$ \\
\hline \multirow[t]{3}{*}{ New Opportunity } & new product/service & $19.9 \%$ \\
\hline & new investment plan & $7.3 \%$ \\
\hline & new partnership & $3.4 \%$ \\
\hline Social Responsibility & COVID-19 related help & $11.0 \%$ \\
\hline
\end{tabular}

This table represents the primary sample and the outcome of the content analysis. In Panel A, we show the number of news articles collected by the search process as the primary sample. In Panel B, the results are presented in terms of response categories and the percentage of news items as per the identified action categories. All the news in the sample were first categorized as action items and then categorized into broader action categories.

Table 2. Examples of news items related to specific firm actions

\begin{tabular}{ll}
\hline Action Items & \multicolumn{1}{c}{ News Headings } \\
\hline $\begin{array}{l}\text { continue operations } \\
\text { maintain contracts } \\
\text { maintain employee cost }\end{array}$ & Maruti Suzuki, Hyundai plan two factory shifts \\
cut employee cost & No pay cuts, all job offers will be honoured by Flipkart \\
cut other costs & After Zomato, Swiggy to lay off 1100 employees to cut costs \\
cut investment budget & Oyo to offload more loss making hotels as virus spoils global plans \\
renegotiate contracts & Ultratech Cement curbs capex to Rs.1000 crore for FY21 \\
new product/service & Oyo suspends payments to hotels; partners say clause not in contract \\
new investment plan & Bajaj Consumer Care launches hand sanitizers \\
new partnership & Amazon India announces 20000 seasonal jobs in customer service \\
COVID-19 related help & Bharti Airtel partners with Apollo to tackle COVID-19 \\
\hline
\end{tabular}

This table presents some examples of news items for different corporate responses. The action items were coded by interpreting the corporate actions from such news items

key role in the economic recovery. Table 2 shows examples of the corporate responses from our sample.

Additionally, we observe strategic differences in how firms responded considering short- as well as long-term benefits. Some firms retained employee costs at the same level (4.9\%). There were other opposite responses, such as cutting investments (1.0\%) versus making new investments (7.3\%), and renegotiating contracts (1.0\%) versus maintaining contracts with partners $(6.3 \%)$.

\section{Conclusion}

COVID-19 has created a sudden disruption to the world's economy, including India's. However, the Indian economy bounced back quickly, showcasing corporate resilience amid the initial shock. In this study, we try to systematically understand Indian corporate responses during the lockdown period, uncovering economic resilience beyond government interventions. Our analysis of corporate actions during the 
most uncertain period suggests that Indian companies mostly focused on employee cost reduction and product or service innovation, apart from operational continuity. There was considerable focus on social responsibility as well. Interestingly, there seems to be wide variation in responses across firms, which could depend upon industry- as well as firm-specific factors. More research and fine-grained analysis are needed to tease out the nuanced variations in responses, as well as impacts, with the ease of availability of data in the future.

\section{Acknowledgement}

The authors acknowledge the helpful comments from the two anonymous reviewers and the editor in improving the paper. The authors thank the Thomas Schmidheiny Centre for Family Enterprise at Indian School of Business for the financial support in conducting this research.

Submitted: April 30, 2021 AEDT, Accepted: June 12, 2021 AEDT 


\section{REFERENCES}

Agrawal, S., Smet, A. D., Lacroix, S., \& Reich, A. (2020). To Emerge Stronger from the COVID-19 Crisis, Companies Should Start Reskilling their Workforces Now. McKinsey Insights. https://www.mckinsey.com/ business-functions/organization/our-insights/to-eme rge-stronger-from-the-covid-19-crisis-companies-sh ould-start-reskilling-their-workforces-now

Ashraf, B. N. (2020). Economic Impact of Government Interventions During the COVID-19 Pandemic: International Evidence from Financial Markets. Journal of Behavioral and Experimental Finance, 27, 100371. https://doi.org/10.1016/j.jbef.2020.100371

Boland, B., De Smet, A., Palter, R., \& Sanghvi, A. (2020). Reimagining the Office and Work Life After COVID-19. Mckinsey \& Company. https://www.mckinsey.com/bu siness-functions/organization/our-insights/reimagini ng-the-office-and-work-life-after-covid-19? cid=othe r-eml-alt-mip-mck\&hlkid=8778afb0af6f4f938879e28 46fe15066\&hctky=11396825\&hdpid=4256de30-f94 2-4b45-948f-9a5d81ac6e68

Buehler, K., Dietz, M., Nadeau, M.-C., Nauck, F., Serino, L., \& White, O. (2020). Stability in the Storm: US Banks in the Pandemic and the Next Normal.

Gaur, A., \& Kumar, M. (2018). A systematic approach to conducting review studies: An assessment of content analysis in 25 years of IB research. Journal of World Business, 53(2), 280-289. https://doi.org/10.1016/j.jw b.2017.11.003

Ghosh, A., Nundy, S., \& Mallick, T. K. (2020). How India is dealing with COVID-19 pandemic. Sensors International, 1(June), 100021. https://doi.org/10.101 6/j.sintl.2020.100021

Han, H., \& Qian, Y. (2020). Did Enterprises' Innovation Ability Increase During the COVID-19 Pandemic? Evidence From Chinese Listed Companies. Asian Economics Letters, 18, 1-5. https://doi.org/10.46557/0 $\underline{01 c .18072}$
Iyke, B. N. (2020). Economic Policy Uncertainty in Times of COVID-19 Pandemic. Asian Economics Letters, 1, 2-5. https://doi.org/10.46557/001c.17665

Lund, S., Ellingrud, K., Hancock, B., \& Manyika, J. (2020). COVID-19 and Jobs: Monitoring the US Impact on People and Places. In McKinsey Global Institute.

Padhan, R., \& Prabheesh, K. P. (2021). The economics of COVID-19 pandemic: A survey. Economic Analysis and Policy, 70, 220-237. https://doi.org/10.1016/j.eap.202 1.02.012

Sha, Y., \& Sharma, S. S. (2020). Research on Pandemics Special Issue of the Journal Emerging Markets Finance and Trade. Emerging Markets Finance and Trade, 56(10), 2133-2137. https://doi.org/10.1080/154 0496x.2020.1795467

Sharma, S. S., \& Sha, Y. (2020). Part A: Special Section on COVID-19 Research. Emerging Markets Finance and Trade, 56(15), 3551-3553. https://doi.org/10.1080/15 40496x.2020.1858617

Shen, H., Zhang, M., Liu, R., \& Hou, F. (2020). Economic Policy Uncertainty and Corporate Innovation: Evidence From China. Asian Economics Letters, October. https://doi.org/10.46557/001c.17192

Wenzel, M. (2021). Strategic responses to crisis. Strategic Management Journal, 42(2), 016-027. http s://doi.org/10.1002/smj.3161

Yang, H., \& Deng, P. (2021). The Impact of COVID-19 and Government Intervention on Stock Markets of OECD Countries. Asian Economics Letters, February. ht tps://doi.org/10.46557/001c.18646 